\title{
Implementation of Two-point Quadrature Gauss-Legendre Method on 2D Gravity Anomaly Modeling in Basins with Density Distribution varied Polynomially as a function of Depth
}

\author{
Implementasi Metode Gauss-Legendre Quadrature Aturan Dua-Titik pada Pemodelan Anomali \\ Gravitasi 2D oleh Cekungan dengan Distribusi Densitas yang Bervariasi Polinomial Terhadap
}

Kedalaman

\author{
Wahyu Srigutomo*, Sesri Santurima, Cahyo Aji Hapsoro, Hairil Anwar, I G. P. F. Soerya Djaja, \\ Kelompok Keahlian Fisika Bumi dan Sistem Kompleks, Fakultas Matematika dan Ilmu Pengetahuan Alam, \\ Institut Teknologi Bandung, Bandung, Indonesia, 40132 \\ *Email: wahyu@fi.itb.ac.id
}

Submit: 8 Februari 2018; Revised: 4 September 2018; Accepted: 10 September 2018

\begin{abstract}
Study of basin geometry basin is important in geosciences and geophysical exploration. Gravity method can be used to address this issue by measuring gravity anomalies on the surface caused by density contrast between the bedrock and the sediment that fills the basin, geometry of the basin and surface topography. Numerically, gravity anomaly modeling can be conducted using two-point rule Gauss-Legendre Quadrature method, for a case where density contrast varies with depth exponentially. Within the scope of this study, gravity anomalies on the surface are significantly affected by the geometry of the curvature of the bedrock as well as the topographic elevation of the surface and the selected density contrast, and are not significantly affected by the undulation of the bedrock curvature.
\end{abstract}

Keywords: basin, gravity anomaly, density contrast, forward modeling, Gauss-Legendre Quadrature method

Abstrak: Kajian mengenai geometri bidang batas antara cekungan (basin) dengan batuan dasar (basement) di bawahnya merupakan hal yang penting dalam geosains serta eksplorasi geofisika. Metode gravitasi dapat digunakan dalam kajian ini dengan cara mengukur anomali gayaberat di permukaan yang disebabkan oleh kontras densitas antara batuan dasar dengan material sedimen pengisi cekungan, geometri cekungan serta topografi permukaan. Secara numerik, pemodelan anomali gayaberat oleh struktur cekungan dilakukan menggunakan metode Gauss-Legendre Quadrature aturan dua-titik, dengan kontras densitas yang bervariasi terhadap kedalaman secara eksponensial. Dalam lingkup kajian ini, anomali gayaberat di permukaan secara signifikan dipengaruhi oleh geometri kelengkungan batuan dasar serta undulasi elevasi topografi di permukaan serta bentuk kontras densitas yang dipilih, dan tidak dipengaruhi secara signifikan oleh undulasi pada kelengkungan batuan dasar.

Kata kunci: cekungan, anomali gayaberat, kontras densitas, pemodelan ke depan, metode Gauss-Legendre Quadrature

\section{PENDAHULUAN}

Studi mengenai morfologi batuan dasar suatu cekungan (basin) melalui metode gravitasi (gayaberat) pada umumnya terkait dengan informasi nilai densitas sedimen pengisi cekungan tersebut. Karakteristik densitas batuan terhadap kedalaman, terutama dalam kasus material sedimen pengisi cekungan lazimnya dicirikan dengan peningkatan nilai densitas terhadap kedalaman atau menurunnya kontras densitas sedimen terhadap batuan dasarnya. Peningkatan nilai densitas terhadap kedalaman ini disebabkan oleh proses kompaksi mekanis dan diagenesis yang pada akhirnya menurunkan nilai porositas Chappell dan Kusznir [2008]. Pada suatu lapisan sedimen, hubungan densitas-kedalaman cukup kompleks, dipengaruhi oleh litologi, sejarah tektonisme, laju pengendapan, fluida pengisi porositas dan tekanan [Chappell dan Kusznir, 2008]. Kompleksitas variasi densitas meningkat seiring terjadinya perlapisan stratigrafi yang tak-seragam, perubahan fasies, sementasi kimiawi serta disrupsi struktural [Garcia, 1996].

Inkorporasi model distribusi densitas yang bervariasi terhadap kedalaman pada sedimen pengisi cekungan merupakan faktor penting dalam khazanah pemodelan dan inversi data gravitasi (terutama pada persoalan upward continuation) telah menjadi fokus beberapa peneliti misalnya Cordell [1973]; Granser [1987]; Cowie dan Karner [1990 ]; Rao [1990]; Engen dkk. [2006], Chappell dan Kusznir [2008]. Mereka mengusulkan formulasi hubungan densitaskedalaman yang berbentuk eksponensial, sedangkan beberapa peneliti lain mengusulkan bentuk polinomial (Garcia [1996], Garcia [2003], Garcia dkk. [2005]). Hubungan densitas dalam bentuk lain yaitu hiperbolik pernah diusulkan juga oleh Litinsky [1989]; Silva dkk. [2006].

Pada prakteknya, hubungan densitas-kedalaman tidak didapatkan secara langsung melainkan dari hubungan kecepatan gelombang-P terhadap kedalaman baik dari studi seismik ataupun sonic velocity log [Ramos, 1976]. 
Nilai kecepatan-kedalaman ini kemudian dikonversi ke dalam ungkapan densitas menurut formulasi empirik yang diusulkan Garner dkk. [1974]. Variasi densitas terhadap kedalaman biasanya dinyatakan dalam bentuk kontras densitas, yaitu dengan cara mengurangkan nilai densitas acuan (misal nilai densitas batuan dasar sebesar 2,67 g/cm3) dari nilai data densitas hasil konversi. Fitting polinomial ataupun eksponensial kemudian dilakukan pada data untuk mendapatkan profil densitas terhadap kedalaman sedimen pengisi cekungan (Garcia [2003], Garcia dkk. [2005]). Variasi densitas-kedalaman ini kemudian menjadi faktor pengendala (constraint) pada skema inversi data gravitasi untuk mendapatkan estimasi morfologi bidang batas antara batuan dasar dengan sedimen di atasnya.

Makalah ini membahas aspek pemodelan ke-depan (forward modeling) anomali gravitasi dua dimensi (2D) yang disebabkan oleh profil batuan dasar (batas bawah cekungan) dan topografi permukaan cekungan serta berbagai fungsi polinomial yang menggambarkan hubungan densitas-kedalaman. Selain bertujuan memahami karakteristik anomali untuk berbagai skenario model cekungan, secara numerik studi ini merupakan langkah awal dari skema interpretasi data gravitasi secara lengkap yaitu tahap inversi.

\section{FORMULASI PEMODELAN}

Geometri persoalan pemodelan ke-depan anomali gravitasi 2D yang disebabkan oleh struktur cekungan dengan densitas sedimen pengisi cekungan bervariasi terhadap kedalaman diperlihatkan pada Gambar 1. Pada skema pemodelan ke-depan ini, parameter fisis sedimen dinyatakan dalam bentuk kontras densitas terhadap nilai densitas batuan dasar. Komponen vertikal medan gravitasi (anomali percepatan gravitasi) di permukaan yang disebabkan oleh sumber bergeometri 2D dibatasi oleh suatu luasan $\Omega$, mengikuti formulasi Garcia [2003] diungkapkan dengan

$$
g\left(x_{0}, z_{0}\right)=2 \gamma \iint_{\Omega} d x d z \frac{\rho(z) Z}{X^{2}+Z^{2}}
$$

di mana $\gamma=6.67 \times 10^{-11} \mathrm{Nm}^{2} \mathrm{~kg}^{-2}$ berupa konstanta gravitasi Newton, $\left(x_{0}, z_{0}\right)$ adalah koordinat titik-titik pengamatan di permukaan, $X=x-x_{0}, Z=z-z_{0}$, and $(x, z)$ menyatakan koordinat titik-titik material di dalam daerah

$$
\Omega=\left\{[x, z]: x_{1} \leq x \leq x_{2}, h_{1}(x) \leq z \leq h_{2}(x)\right\}
$$

Tubuh sumber dibatasi oleh $x_{1} \leq x \leq x_{2}$, di mana $\mathrm{x}$ menyatakan jarak jarak horizontal, sedangkan dalam arah vertikal dibatasi oleh fungsi $h_{1}(x)$ dan $h_{2}(x)$ dan kontras densitas tubuh sumber diasumsikan dapat dinyatakan dalam bentuk polinomial $\rho(z)=p+q z+r z^{2}+s z^{3}$, dengan $\mathrm{p}, \mathrm{q}, \mathrm{r}$, dan s adalah koefisien-koefisien hubungan kontras densitas-kedalaman. Fungsi $h_{1}(x)$ dan $h_{2}(x)$ dapat berupa nilai diskret pada posisi-posisi horizontal dengan spasi yang sama, bentuk polinomial ataupun deret Fourier. Jika diinginkan ungkapan kontras densitas yang juga merupakan fungsi $\mathrm{x}$ selain $\mathrm{z}$, maka kontras densitas akan berbentuk $\rho(z)=p(x)+q(x) z+r(x) z^{2}+s(x) z^{3}$

Garcia [2003] memecahkan Persamaan (1) dengan dua tahap: pertama, menyelesaikan secara analitik integran yang bergantung $\mathrm{z}$,

$$
g\left(x_{0}, z_{0}\right)=2 \gamma \int_{x_{1}}^{x_{2}} d x\left\{\int_{h_{1}(x)}^{h_{2}(x)} \frac{\rho(z) Z}{X^{2}+Z^{2}}\right\}
$$

yang setelah diturunkan berbentuk:

$$
\begin{array}{r}
g\left(x_{0}, z_{0}\right)=2 \gamma \int_{x_{1}}^{x_{2}} d x\left\{\frac{1}{2}\left[\rho\left(z_{0}\right)-\left[r+3 s z_{0}\right] X^{2}\right]\right. \\
x \ln \left(X^{2}+Z^{2}\right)+\left[s X^{2}-\rho\left(z_{0}\right)\right] X \arctan \left(\frac{Z}{X}\right), \\
\left.+\left[\rho\left(z_{0}\right)+s X^{2}\right] Z+\frac{\left(r+3 s z_{0}\right) Z^{2}}{2}+\frac{s Z^{3}}{3}\right\}\left.\right|_{h_{1}(x)} ^{h_{2}(x)}
\end{array}
$$

dengan $\rho\left(z_{0}\right)=q+2 r z_{0}+3 s z_{0}^{2}$ berupa turunan kontras densitas terhadap kedalaman yang dihitung di titik $z_{0}$. Kedua, melakukan integrasi terhadap variabel $\mathrm{x}$ dilakukan secara numerik dengan memanfaatkan metode GaussLegendre Quadrature 32 simpul [Davis dan Polonsky, 1972] seperti yang dilakukan Garcia [2003] dan Garcia dkk. [2005]. Pada makalah ini, metode Gauss-Legendre Quadrature diimplementasikan menggunakan skema aturan dua-titik (two-point rule) seperti yang dituangkan dalam Abramowitz dan Stegun [1970] serta secara rinci dibahas dalam Mathews dan Fink [1999].

Persamaan (4) dapat dilihat dari sudut pandang metode Gauss-Legendre Quadrature sebagai integral tertentu

$$
\int_{x_{2}}^{x_{1}} f(x) d x
$$

dengan fungsi $f(x)$ berupa semua ungkapan yang berada di dalam tanda kurung kurawal dan $x_{1}<x<x_{2}$. Pada metode Gauss-Legendre Quadrature, fungsi integral yang akan dihitung secara numerik berada pada rentang $[-1,1]$ dan untuk skema aturan dua titik, aproksimasi integralnya berbentuk

$$
\begin{array}{r}
\int_{1}^{-1} f(x) d x \approx \Sigma_{2}^{i=1} w_{i} f\left(x_{i}\right) \\
=w_{1} f\left(x_{1}\right) w_{2} f\left(x_{2}\right)=f\left(=\frac{-1}{\sqrt{3}}\right)+f\left(=\frac{1}{\sqrt{3}}\right)
\end{array}
$$

di mana $w_{i}$ adalah bobot-bobot quadrature yang keduanya bernilai 1 dan $x_{i}$ adalah simpul tempat fungsi dihitung. Pada metode Gauss-Legendre Quadrature, Persamaan (5) harus ditransformasi menjadi:

$$
\int_{x_{2}}^{x_{1}} f(x) d x \approx \frac{x_{2}-x_{1}}{2} \Sigma_{2}^{i=1} w_{i} f\left(\frac{x_{2}-x_{1}}{2} x_{i}+\frac{x_{2}+x_{1}}{2}\right)
$$

\section{IMPLEMENTASI NUMERIK}

Tubuh sumber antara $x_{1}$ dan $x_{2}$ dipartisi ke dalam $M$ buah segmen. Semua titik sumber berada di dalam $\Omega$ baik pada garis-garis vertikal segmen maupun di antara dua garis tersebut dan dibatasi oleh fungsi $h_{1}(x)$ dan $h_{2}(x)$ seperti diperlihatkan pada Gambar 2. Nilai $M$ akan terkait dengan waktu 

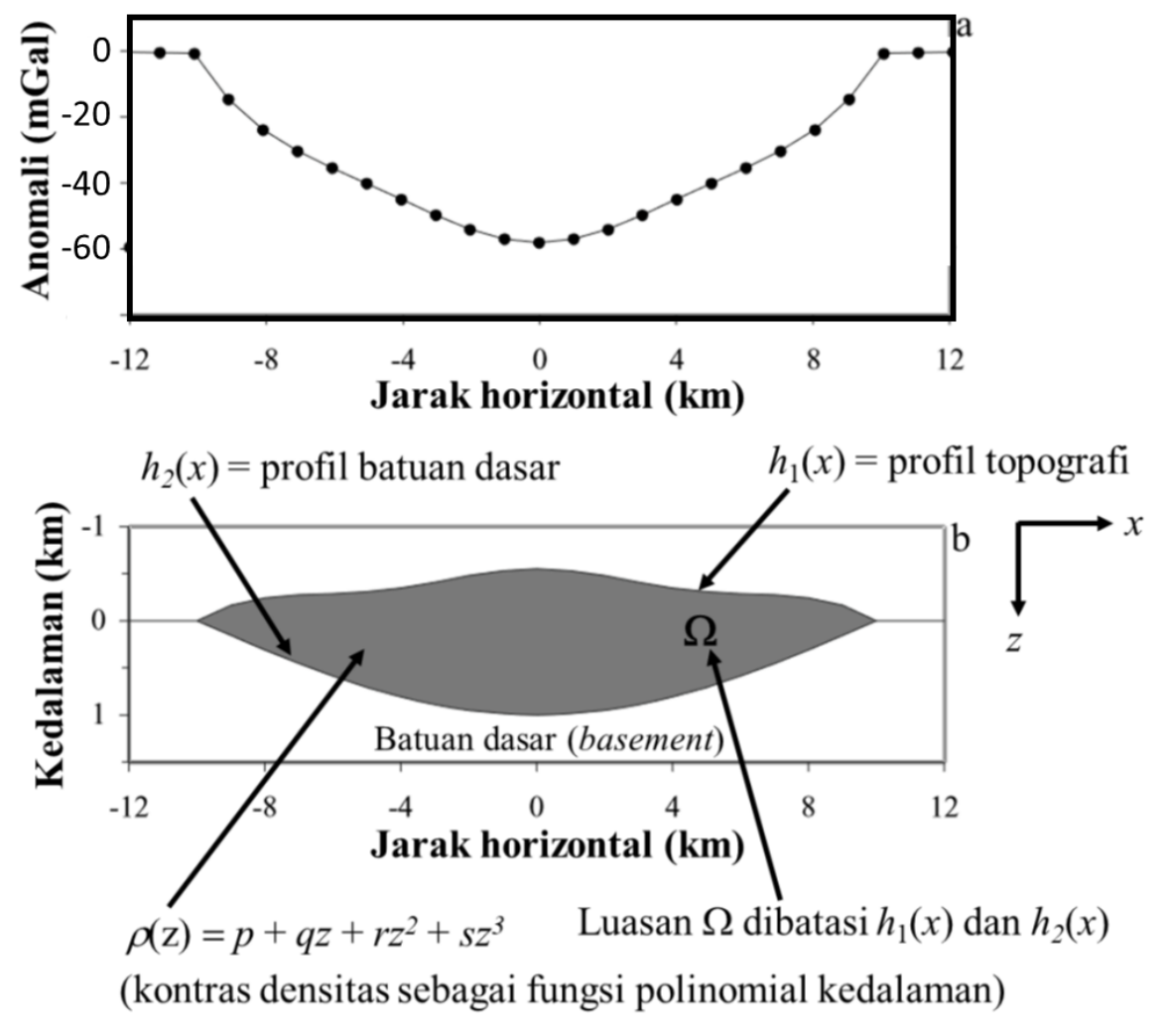

Gambar 1. (a) Ilustrasi anomali gravity yang disebabkan oleh tubuh sumber berupa sedimen pengisi cekungan. (b) Geometri model cekungan beserta kontras densitas sebagai fungsi kedalaman berbentuk polinomial (dimodifikasi dari Garcia [2003].

komputasi dan akurasi. Semakin besar nilai $M$ maka waktu komputasi akan meningkat dengan akurasi aproksimasi integral yang semakin mendekati nilai sesungguhnya. Pada studi kali ini, nilai $M$ adalah 750. Persamaan (7) kemudian dapat ditulis dalam bentuk matriks:

$$
\int_{x_{2}}^{x_{1}} f(x) d x \approx \frac{x_{2}-x_{1}}{2} \Sigma_{2}^{i=1} w_{i} G_{i}
$$

di mana

$$
G_{i}=\left(\frac{x_{2}-x_{1}}{2} x_{i}+\frac{x_{2}+x_{1}}{2}\right)
$$

yang dengan demikian, untuk $M$ buah segmen akan kita dapatkan bentuk matriks berikut:

$$
\Sigma_{M}^{i=1} \Sigma_{2}^{i=1} w_{i} G_{j i}=\left[\begin{array}{cc}
G_{11} & G_{12} \\
G_{21} & G_{22} \\
\ldots & \ldots \\
G_{M 1} & G_{M 2}
\end{array}\right]\left[\begin{array}{l}
w_{1} \\
w_{2}
\end{array}\right]
$$

\section{HASIL PEMODELAN DAN PEMBAHASAN}

Pada bagian ini, pemodelan anomali gravitasi karena tubuh sumber berupa cekungan atau geometri yang selaras seperti halnya graben dengan kontras densitas konstan maupun bervariasi terhadap kedalaman secara polinomial dilakukan pada berbagai geometri cekungan, yaitu untuk berbagai fungsi $h_{1}(x)$ dan $h_{2}(x)$. Tujuannya adalah untuk memahami efek-efek topografi, serta profil cekungan serta kombinasi keduanya. Agar lebih realistis, variasi-variasi densitas terhadap kedalaman yang berbentuk polinomial diambil dari beberapa kasus interpretasi data real dari beberapa cekungan yang telah diteliti beberapa penulis, yaitu: Serikat

1. Graben San Jacinto, Southern California, Amerika

Graben ini merupakan cekungan transtensional yang terbentuk karena pergerakan dilatasional menganan yang terjadi pada zona sesar San Jacinto [Matti dan Morton, 1993]. Interpretasi data gravitasi residual pada graben San Jacinto telah dilakukan olen Garcia [2003] dengan menggunakan nilai kontras densitas $\rho(z)=-0,5491+0,2682 z-0,0581 z^{2}+0,0053 z^{3}$. Nilai ini didapatkan dari least-squares fitting fungsi densitas eksponensial yang sebelumnya digunakan Cordell [1973].

2. Cekungan Sayula, Jalisco, Meksiko

Daerah Sayula merupakan bagian dari satuan geomorfologi yang lebih besar dikenal dengan nama Graben Tepic-Chapala yang mewadahi berbagai depresi tektonik. Seiring dengan terjadinya beberapa episode glasial, besarnya curah hujan menenggelamkan daratan dan meninggalkan jejak berupa danau yang besar Valdez dkk. [2006]. Untuk mengidentifikasi profil batuan dasar cekungan Sayula, Garcia [2003] menggunakan nilai kontras densitas $\rho(z)=-0,8+0,7147 z-0,0229 z^{2}$. 


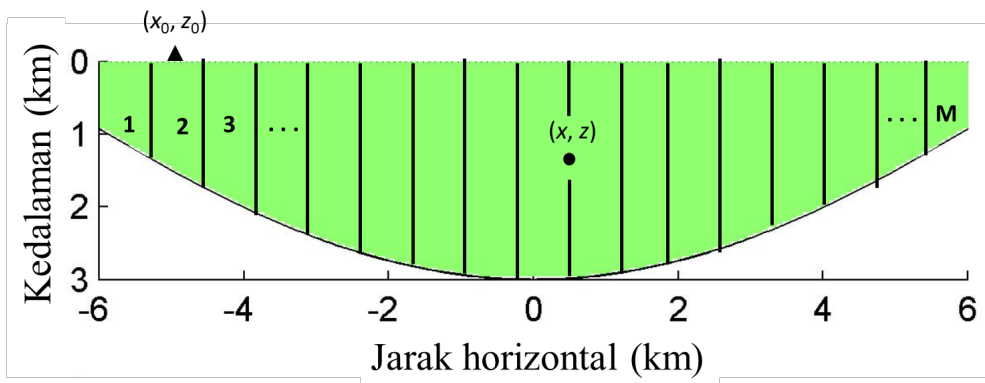

Gambar 2. Ilustrasi partisi tubuh sumber ke dalam $M$ buah segmen. $\left(x_{0}, z_{0}\right)$ adalah koordinat titik pengamatan di permukaan dan $(\mathrm{x}, \mathrm{z})$ menyatakan koordinat titik-titik sumber pada cekungan
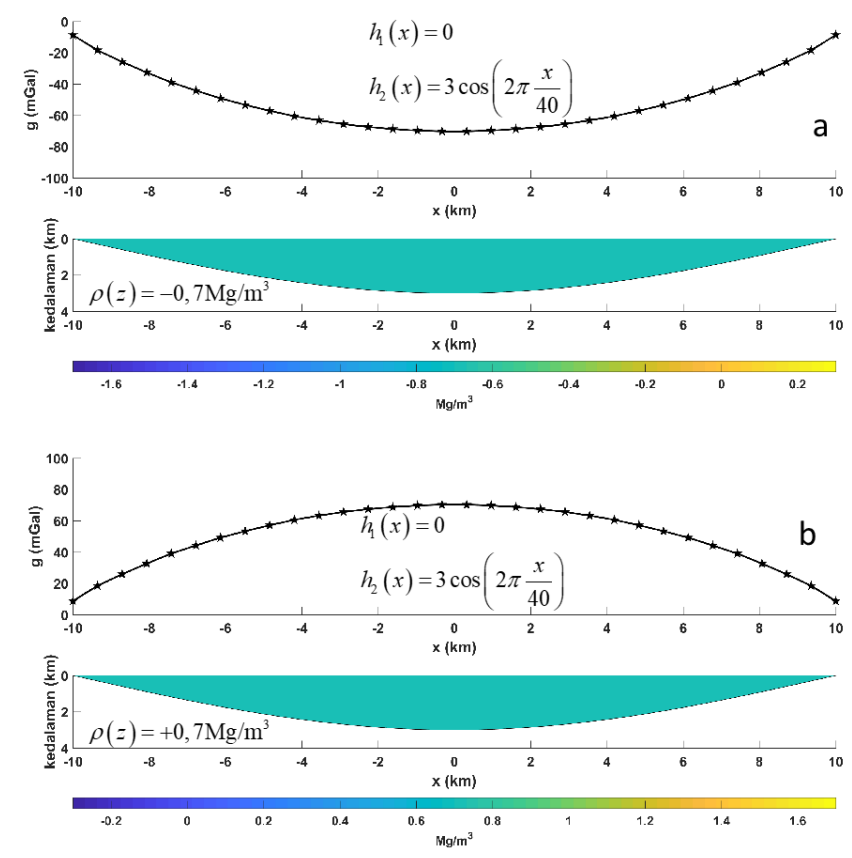
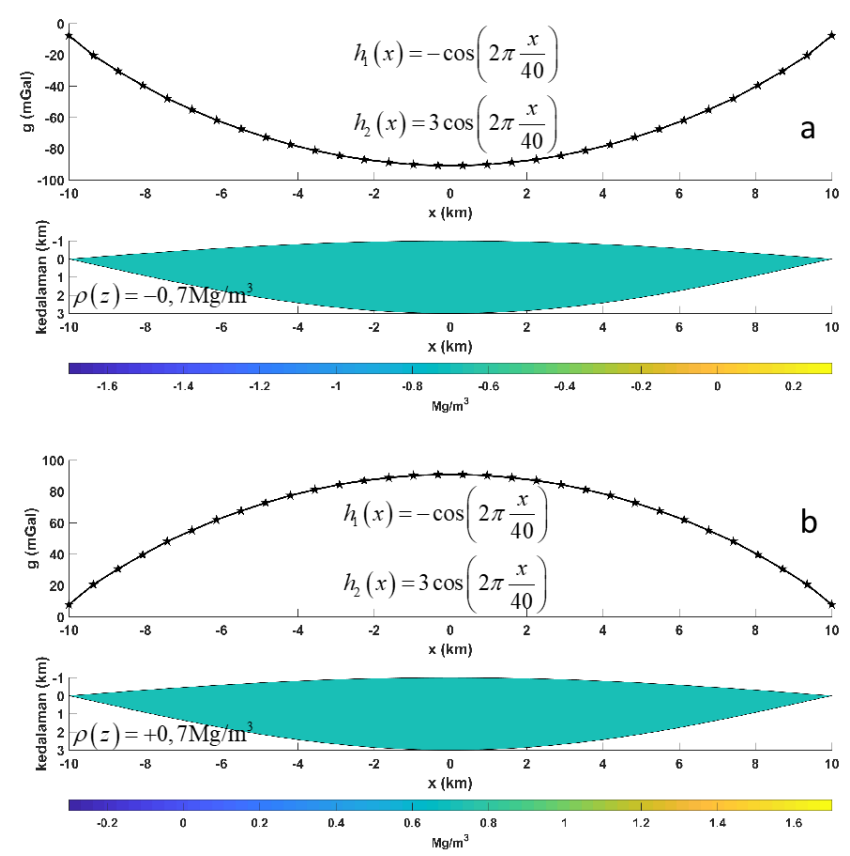

Gambar 3. (a) Model cekungan dengan kontras densitas konstan yaitu (a) $-0,7 \mathrm{Mg} / \mathrm{m}^{3}$ (=-700 $\mathrm{kg} / \mathrm{m}^{3}$ ) dan (b) $+0,7 \mathrm{Mg} / \mathrm{m}^{3}$. Topografi permukaan memiliki elevasi nol (datar) dan bentuk geometri batuan dasar mengikuti deret Fourier berbentuk fungsi cosinus.

3. Cekungan Sebastian Vizcaino, Baja California Sur, Meksiko

Cekungan ini mewadahi lapisan sedimen laut yang tebal yang terakumulasi pada daerah busur depan dari suatu margin kompresif yang membentang sepanjang Amerika Utara bagian barat selama periode Mesozoik dan Tersier. Kontras densitas berbentuk $\rho(z)=-0,7+0,2548 z-0,0273 z^{2}$ digunakan oleh Garcia dkk. [2005] sebagai hasil fitting data densitas yang sebelumnya dikonversi dari hubungan densitas terhadap kecepatan seismik menggunakan polinomial orde dua.

Gambar 3 memperlihatkan suatu model cekungan sederhana dengan material pengisi cekungan (tubuh sumber) yang memiliki kontras densitas konstan. Topografi cekungan merupakan garis mendatar dengan elevasi nol,
Gambar 4. (a) Model cekungan dengan kontras densitas konstan yaitu (a) $-0,7 \mathrm{Mg} / \mathrm{m}^{3}$ (=1000 $\mathrm{kg} / \mathrm{m} 3$ ) dan (b) $+0,7 \mathrm{Mg} / \mathrm{m}^{3}$. Topografi permukaan memiliki kelengkungan elevasi dan sefasa dan bentuk geometri batuan dasar mengikuti deret Fourier berbentuk fungsi cosinus.

dinyatakan dengan persamaan batas $h_{1}(x)=0$ sedangkan geometri batuan dasar dinyatakan dengan persamaan batas dalam deret Fourier yang berbentuk cosinus yaitu $h_{2}(x)=$ $3 \cos 2 \pi \frac{x}{40}$. Nilai kontras densitas ditentukan dua nilai yaitu pertama, nilai negatif $\rho(z)=-0,7 \mathrm{Mg} / \mathrm{m}^{3}$ yang setara dengan $-700 \mathrm{~kg} / \mathrm{m}^{3}$ dan kedua, nilai kontras densitas positif $\rho(z)=+0,7 \mathrm{Mg} / \mathrm{m}^{3}$. Anomali gayaberat diukur (dihitung) di permukaan oleh sebanyak 32 stasiun dengan jarak antar stasiun sama sepanjang $20 \mathrm{~km}$. Pada kasus kontras densitas negatif, anomali gayaberat memiliki pola kurvatur melengkung ke bawah dan bernilai negatif bersesuaian dengan geometri batuan dasarnya. Hal ini merupakan kasus yang tipikal pada kondisi di lapangan yang sesungguhnya. Sedangkan pada kasus kontras densitas positif, anomali gayaberat 

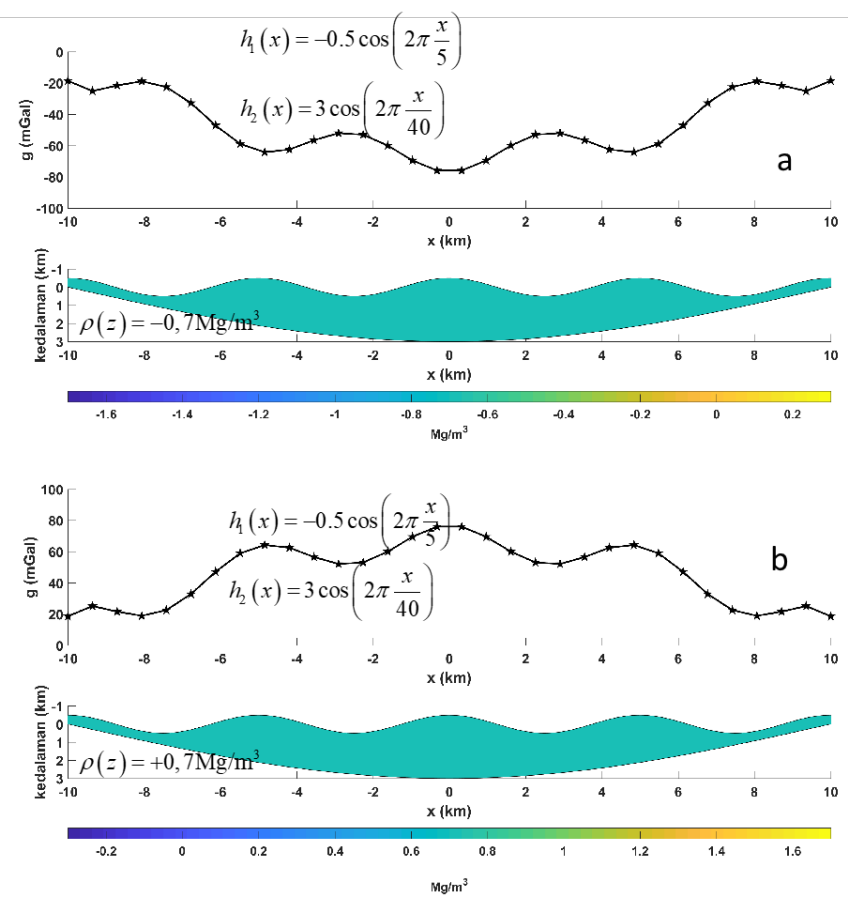

Gambar 5. (a) Model cekungan dengan kontras densitas konstan yaitu (a) $-0,7 \mathrm{Mg} / \mathrm{m} 3$ (=1000 kg/m3) dan (b) +0,7 Mg/m3. Topografi permukaan berundulasi dengan panjang gelombang yang lebih pendek dari kelengkungan geometri batuan dasar.

meruapakan pencerminan terhadap sumbu horizontal dengan nilai-nilai yang positif.

Kehadiran elevasi topografi yang diwakili oleh nilai $\left(h_{1}(x)\right.$ tidak akan berkontribusi banyak dalam mengubah bentuk gelombang anomali apabila kelengkungan topografi sefasa dan berbeda tanda, yaitu $h_{1}(x)=-\cos 2 \pi \frac{x}{40}$ dengan kelengkungan geometri cekungan seperti yang terlihat Gambar 4. Namun demikian, penambahan massa akan menyebabkan anomali gayaberat terukur di permukaan membesar baik ke arah negative untuk kontras densitas negatif dan ke arah positif untuk kontras densitas positif.

Undulasi pada topografi dengan panjang gelombang kelengkungan yang lebih kecil dibanding kelengkungan geometri batuan dasar akan menghasilkan pola anomali gayaberat yang terdiri dari pola melengkung berpanjang gelombang besar ditumpangi pola undulasi dengan panjang gelombang yang lebih kecil. Kondisi ini diperlihatkan pada Gambar 5, baik untuk kontras densitas yang negatif maupun positif.

Berikutnya adalah model-model cekungan dengan kontras densitas material sedimen pengisi cekungan yang bervariasi secara polinomial dengan kondisi topografi yang mendatar. Bentuk-bentuk yang dipilih adalah nilai yang digunakan oleh beberapa penulis sebelumnya pada kasus graben San Jacinto dan cekungan sayula [Garcia, 2003] serta cekungan Sebastian Vizcaino [Garcia dkk., 2005] seperti diilustrasikan pada Gambar 6(a) hingga 6(c). Kedalalam maksimum batuan dasar adalah $3 \mathrm{~km}$ pada model-model cekungan ini. Pada nilai kontras densitas graben San Jacinto dan cekungan Sebastian Vizcaino, anomali gayaberat negatif teramati secara teoretik di sepanjang permukaan.
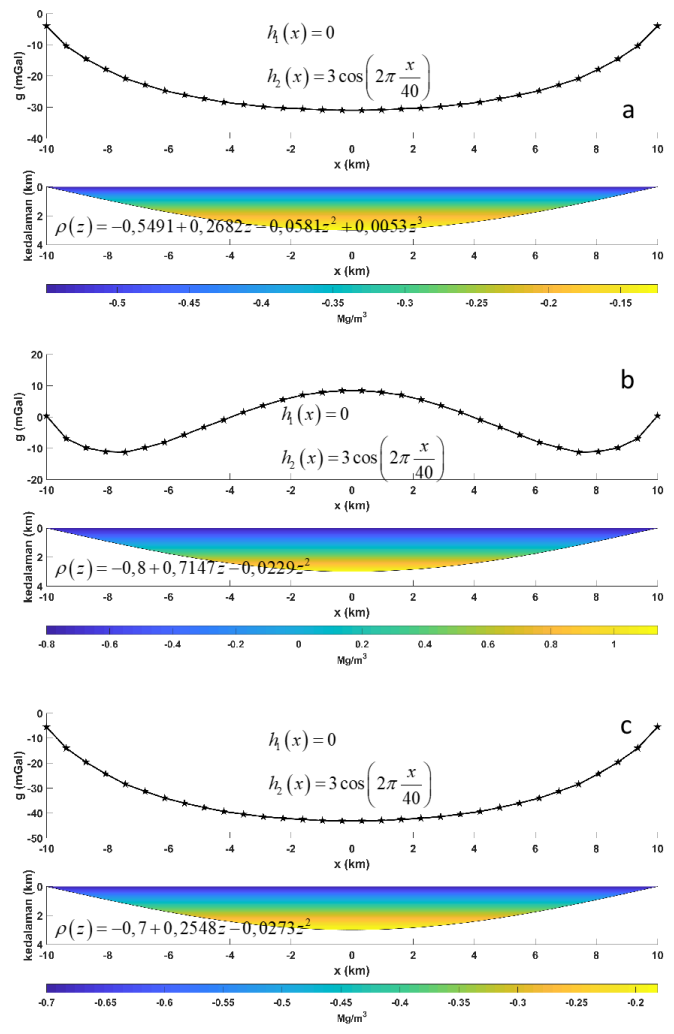

Gambar 6. Model cekungan dengan topografi mendatar untuk (a) kasus kontras densitas yang menurun terhadap kedalaman sesuai dengan kasus graben San Jacinto, (b) cekungan Sayula, dan (c) cekungan Sebastian Vizcaino

Namun pada kasus nilai kontras densitas cekungan Sayula, anomali gayaberat mengalami kenaikan ke arah nilai positif dan bernilai maksimum di tengah-tengah cekungan. Hal ini mengindikasikan bahwa model nilai kontras densitas yang berubah terhadap kedalaman dengan koefisien-koefisien kontras densitas p, q, r, dan s yang mirip dengan kasus cekungan Sayula hanya valid untuk cekungan-cekungan dengan batuan dasar yang dangkal. Secara matematik pada nilai kedalaman tertentu nilai kontras densitas akan melampaui nilai nol dan menjadi positif sehingga menyebabkan terukurnya nilai anomali gayaberat positif. Garcia [2003] menemukan bahwa kedalaman maksimum cekungan Sayula dalam interpretasinya adalah sekitar $1 \mathrm{~km}$, jauh lebih dangkal dari model pada Gambar 6 yaitu $3 \mathrm{~km}$. Kondisi yang digambarkan pada Gambar 6(b) dapat pula bersesuaian dengan graben yang berisi material dengan densitas lebih rendah (misal material piroklastik atau batuan alterasi yang di bawahnya terdapat batuan instrusif sebagai sumber panas (misal pada Santos dan Rivas [2009].

Penambahan kelengkungan topografi $h_{1}(x)=$ $-\cos 2 \pi \frac{x}{40}$ pada model cekungan (Gambar 7) semakin mempertajam nilai anomali gayaberat negatif terutama pada nilai kontras densitas graben San jacinto (a) dan cekungan Sebastian Vizcaino (c). Kehadiran topografi juga menekan penajaman anomali gayaberat positif pada bagian tengah model dengan nilai kontras densitas cekungan Sayula. Hasil ini mengkonfirmasi signifikansi 

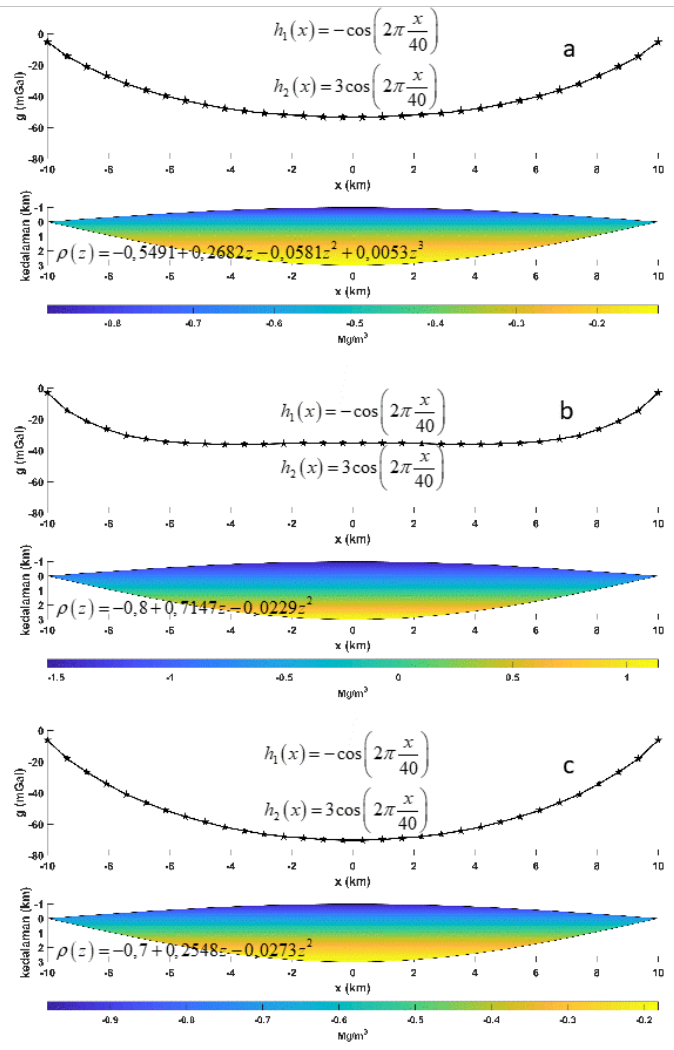

Gambar 7. Model cekungan dengan kelengkungan topografi sefasa namun berbeda tanda dengan kelengkungan geometri batuan dasar. Nilai elevasi topografi maksimum adalah $1 \mathrm{~km}$ di tengahtengah model untuk (a) kasus kontras densitas yang menurun terhadap kedalaman sesuai dengan kasus graben San Jacinto, (b) cekungan Sayula, dan (c) cekungan Sebastian Vizcaino

efek-efek topografi dalam interpretasi geometri batuan dasar cekungan.

Kehadiran undulasi topografi juga akan secara signifikan mengubah fitur anomali gayaberat terukur di permukaan. Kondisi ini diilustrasikan pada Gambar 8 di mana topografi permukaan berundulasi dikarakterisasi persamaan batas $h_{1}(x)=-0,5 \cos 2 \pi \frac{x}{5}$ dengan elavasi maksimum $1 \mathrm{~km}$. Untuk kasus (a) dan (c) kelengkungan anomali gayaberat negatif bergelombang panjang masih terlihat sebagai jejakjejak fitur batuan dasar ditumpangi oleh undulasi anomali yang bergelombang pendek sebagai cerminan undulasi topografi. Pada kasus (c), anomali gayaberat mengalami penajaman ke arah nilai positif dan undulasi pada anomali terlihat jelas hanya pada bagian tepi-tepi cekungan.

Untuk melihat pengaruh undulasi pada kelengkungan batuan dasar, variasi geometri pada salah satu model yaitu model pada Gambar 6(c), 7(c), dan 8(c) atau kasus nilai kontras densitas cekungan Sebastian Vizcaino dengan menambahkan suku sinus sebagai representasi undulasi bergelombang pendek yang ditumpangkan pada bentuk cekungan. Hal ini diimplementasikan dengan menerapkan persamaan batas $h_{2}(x)=3 \cos 2 \pi \frac{x}{40}+0,25 \sin 2 \pi \frac{x}{40}$. Model-model cekungan pada kasus ini dapat dilihat pada Gambar 9. Dalam batasan pemodelan yang dilakukan pada studi kali ini, terlihat bahwa undulasi tumpangan pada ke-
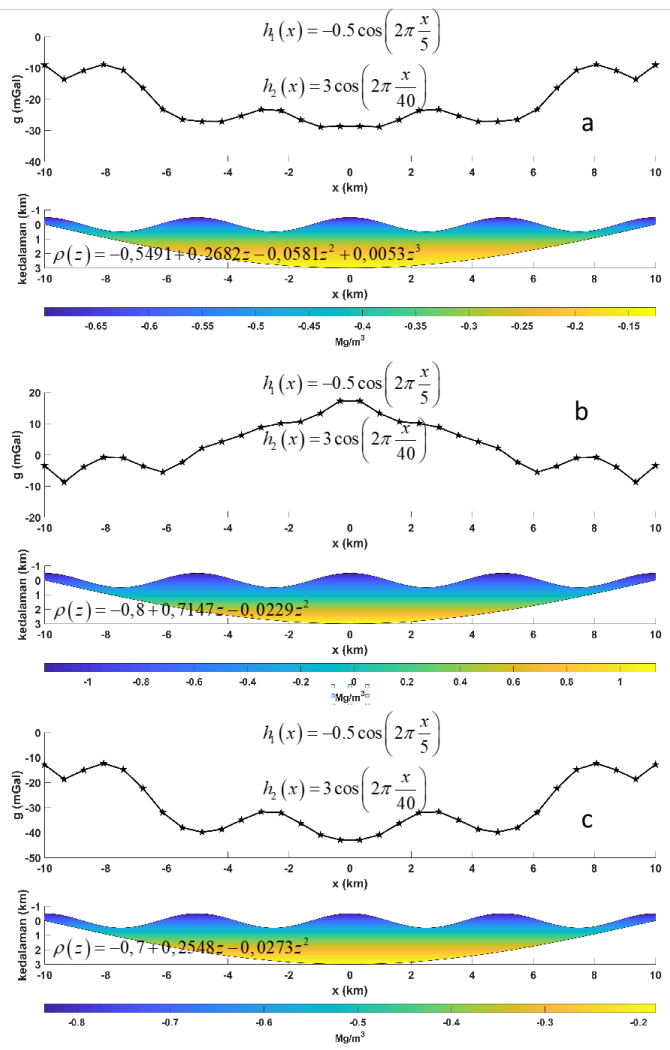

Gambar 8. Model cekungan dengan kelengkungan topografi yang nerundulasi dengan elevasi maksimum $0,5 \mathrm{~km}$ untuk (a) kasus kontras densitas yang menurun terhadap kedalaman sesuai dengan kasus graben San Jacinto, (b) cekungan Sayula, dan (c) cekungan Sebastian Vizcaino.

lengkungan geometri cekungan tidak berkontribusi banyak mengubah kelengkungan anomali gayaberat yang berarti juga bahwa pada pengukuran sesungguhnya, proses inversi untuk menemukan kelengkungan batuan dasar dengan skema pemodelan ke depan dalam studi ini berkemungkinan menekan detail undulasi berpanjang gelombang pendek yang menumpang fitur kelengkungan batuan dasar.

\section{STUDI LANJUTAN}

Skema pemodelan ke depan anomali gayaberat dengan tubuh sumber berupa meterial sedimen pengisi cekungan yang bervariasi terhadap kedalaman ini perlu juga mengakomodir bentuk variasi kontras densitas parabolik semisal):

$$
\rho(z)=\frac{\rho_{0}^{3}}{\left(\rho_{0}-\alpha z\right)^{2}}
$$

dengan $\rho_{0}$ berupa kontras densitas hasil ekstrapolasi ke permukaan dan $\alpha$ merupakan koefisien hasil fitting Persamaan 11 terhadap informasi kontras densitas-kedalaman yang diketahui di lapangan. Selain itu, bentuk variasi kontas densitas terhadap kedalaman yang mengikuti pola eksponensial perlu dipertimbangkan dalam skema pemodelan ke depan [Granser, 1987]: 

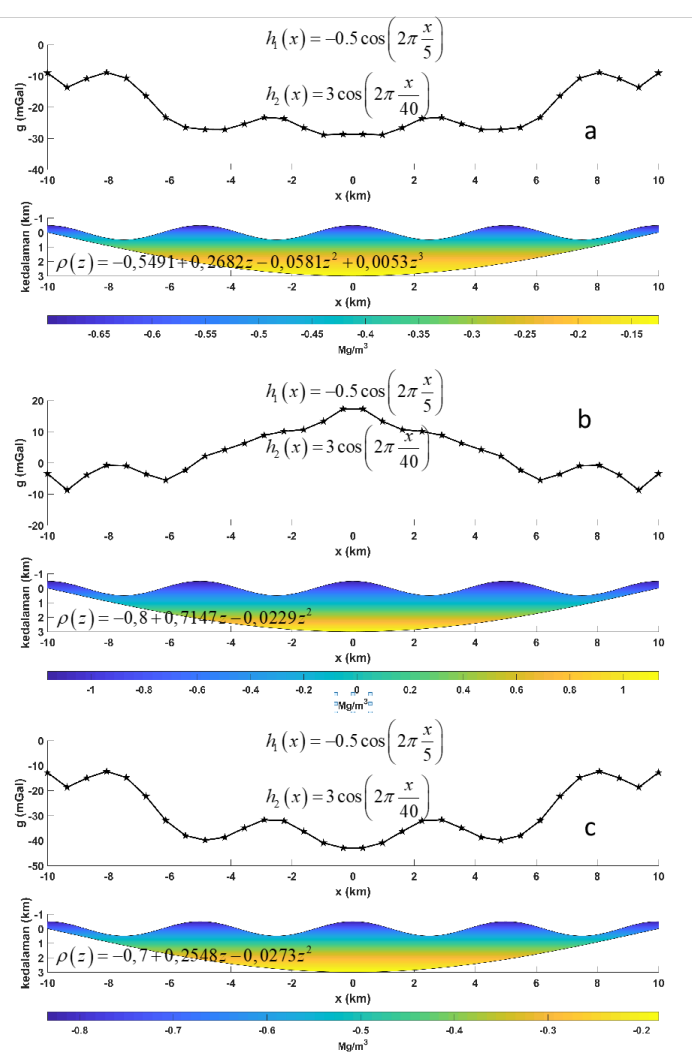

Gambar 9. Model cekungan dengan kelengkungan topografi yang nerundulasi dengan elevasi maksimum 0,5 km untuk (a) kasus kontras densitas yang menurun terhadap kedalaman sesuai dengan kasus graben San Jacinto, (b) cekungan Sayula, dan (c) cekungan Sebastian Vizcaino. Pada semua kasus, kelengkungan cekungan bergelombang panjang ditumpangi oleh undulasi bergelombang pendek.

$$
\rho(z)=d_{0} e^{-\lambda z}
$$

dengan $d_{0}$ berupa kontras densitas di permukaan dan $\lambda$ adalah konstanta laju penurunan nilai densitas terhadap kedalaman.

Persoalan sesungguhnya di lapangan adalah persoalan mengestimasi bentuk geometri batuan dasar dari suatu cekungan dari data anomali gayaberat yang terukur di permukaan. Oleh karena itu, perlu dikembangkan skema inversi data gayaberat yang efisien dan cocok dengan persoalan pemodelan ke depan yang dihadapi. Persoalan inversi untuk estimasi geometri cekungan adalah persoalan inversi nonlinier dengan jumlah data lebih besar dari jumlah parameter model yang dicari (kasus over-determined).

\section{KESIMPULAN}

Pemodelan ke depan anomali gayaberat yang disebkan oleh cekungan (basin) dengan kontras densitas sedimen pengisi cekungan yang bervariasi terhadap kedalaman secara polinomial telah dilakukan untuk model geometri batuan dasar yang direpresentasikan oleh deret Fourier cosinus maupun sinus. Anomali gayaberat dihitung melalui dua tahap analitik dan tahap integrasi numerik. Metode Gauss-Legendre Quadrature dengan aturan dua-titik berhasil diterapkan dalam menyelesaikan integrasi numerik di atas. Pemodelan ini diterapkan pertama-tama untuk kasus kontras densitas tetap untuk berbagai variasi geometri cekungan, kemudian dilanjutkan dengan skema kontras densitas yang bervariasi secara eksponesial. Beberapa skema kontras densitas dari penelitian real di lapangan para penulis terdahulu diterapkan dalam kajian ini untuk menjamin ke-realistikan pemodelan. Dalam lingkup kajian yang dilakukan, relief topografi permukaan merupakan faktor yang cukup signifikan mengkarakterisasi anomali gayaberat dari suatu cekungan. Kemampuan untuk mengidentifikasi fitur-fitur anomali bergelombang panjang yang disebabkan bentuk geometri cekungan (batas batuan dasar) serta fitur-fitur bergelombang lebih pendek yang disebabkan undulasi topografi permukaan menjadi sangat penting dalam kajian anomali gayaberat yang disebabkan suatu cekungan.

\section{DAFTAR PUSTAKA}

Abramowitz, M. dan Stegun, I. A. (eds), 1970. Handbook of Mathematical Functions, Dover Publications Inc., New York.

Chakravarthi, V., Raghuram, H. M. dan Singh, S. B., 2002. $3 D$ forward gravity modeling of density interfaces above which the density contrast varies continuously with depth: Computers \& Geosciences, 28, pp 53-57.

Chappell, A. dan Kusznir, N., 2008. An algorithm to calculate the gravity anomaly of sedimentary basins with exponential density-depth relationships, Geophysical Prospecting, 56, pp 249-258.

Cordell, L., 1973. Gravity anomalies using an exponential density-depth function - San Jacinto Graben, California: Geophysics, 38, pp 684-690.

Cowie P.A. dan Karner G.D. 1990. Gravity effect of sediment compaction: Examplesfromthe North Sea and the Rhine Graben. Earth and Planetary Science Letters 99, pp 141-153.

Davis, P. J. dan Polonsky I., 1972. Numerical interpolation, differentiation and integration. In: Handbook of Mathematical Functions with Formulas, Graphs, and Mathematical Tables (eds M. Abramowitz and I.A. Stegun), Dover Publications Inc., Chapter 25, pp. 875-924.

Engen O., Frazer L.N., Wessel P. and Faleide J.I. 2006. Prediction of sediment thickness in the Norwegian-Greenland Sea from gravity inversion. Journal of Geophysical Research 111, B11403.

Garcia-Abdeslem, J., 1996. GL2D: A FORTRAN program to compute the gravity anomaly of a 2-D prism where density varies as a function of depth, Computers \& Geosciences, 22 , pp 823-826.

Garcia-Abdeslem, J., 2003. 2D modeling and inversion of gravity data using density contrast varying with depth and source-basement geometry described by the Fourier series, Geophysics, 68, pp 1909-1916.

Garcia-Abdeslem, J., Romo, J. M., Gomez-Trevino, E., Ramırez-Hernandez, J., Esparza-Hernandez, F. J. dan Flores-Luna, C. F., 2005. A constrained 2D gravity model 
of the Sebastian Vizcaino Basin, Baja California Sur, Mexico, Geophysical Prospecting, 53, pp 755-765.

Gardner, G.H.F., Gardner,L.W., dan Gregory, A.R., 1974. Formation velocity and density-The diagnostic basics for stratigraphic traps: Geophysics, 39, pp 770-780.

Granser, H., 1987. Three-dimensional interpretation of gravity data from sedimentary basins using an exponential density-depth function: Geophysical Prospecting, 35, pp 1030-1041, doi: 10.1111/j.1365-2478.1987.tb00858.x.

Litinsky, V. A., 1989. Concept of effective density: Key to gravity depth determinations for sedimentary basins: Geophysics, 54, pp 1474-1482, doi: 10.1190/1.1442611.

Mathews, J. H. dan Fink, K. D., 1999. Numerical Methods using Matlab, Prentice Hall, Upper Saddle River, New Jersey, pp 342-398.

Matti, J.C., dan Morton, D.M., 1993. Paleogeographic evolution of the San Andreas fault in southern California: a reconstruction based on a new cross-fault correlation, in Powell, R.E., Weldon, R.J., and Matti, J.C., eds., The San Andreas fault system: displacement, palinspastic reconstruction, and geologic evolution: Geological Society of America Memoir 178, p. 107-159.

Ramos-Garcia, F., 1976. Prospeccion geofisica en la Penınsula de Baja California. III. Simposium de Geologıa del Subsuelo, PEMEX, Superintendencia General de Exploracion, Distrito Frontera Norte, Reynosa, Tamaulipas, Mexico, pp. 61-72

Rao, D. B., 1990. Analysis of gravity anomalies of sedimentary basins by an asymmetrical trapezoid model with quadratic density function, Geophysics, 55, 226-231.

Santos, P. A. dan Rivas, J. A., 2009. Gravity Surveys Contribution to Geothermal Exploration in El Salvador: the Cases of Berlin, Ahuachapán and San Vicente Areas, Short Course on Surface Exploration for Geothermal Resources, UNU-GTP and LaGeo, in Ahuachapan and Santa Tecla, El Salvador, 17-30 October, 2009, pp 1-6.

Sari, C. dan Salk, M., 2002. Analysis of gravity anomalies with hyperbolic density contrast: An application to the gravity data of Western Anatolia, Journal Of The Balkan Geophysical Society, Vol. 5, No 3, pp 87-96.

Silva, J. B. C., D. C. L. Costa, and V. C. F. Barbosa, 2006. Gravity inversion of basementrelief and estimation of density contrast variation with depth: Geophysics, 71, no. 5, J51-J58, doi: 10.1190/1.2236383.

Valdez, F., Emphoux, J. P., Acosta, R., Ramírez, S., Reveles, J. dan Schöndube, O., 2006. Late Formative Archaeology in the Sayula Basin of Southern Jalisco. Ancient Mesoamerica, 17, pp 297-311, doi:10.1017/S0956536106060147 